\title{
Volcanic-Hazard Zonation for Glacier Peak Volcano, Washington
}

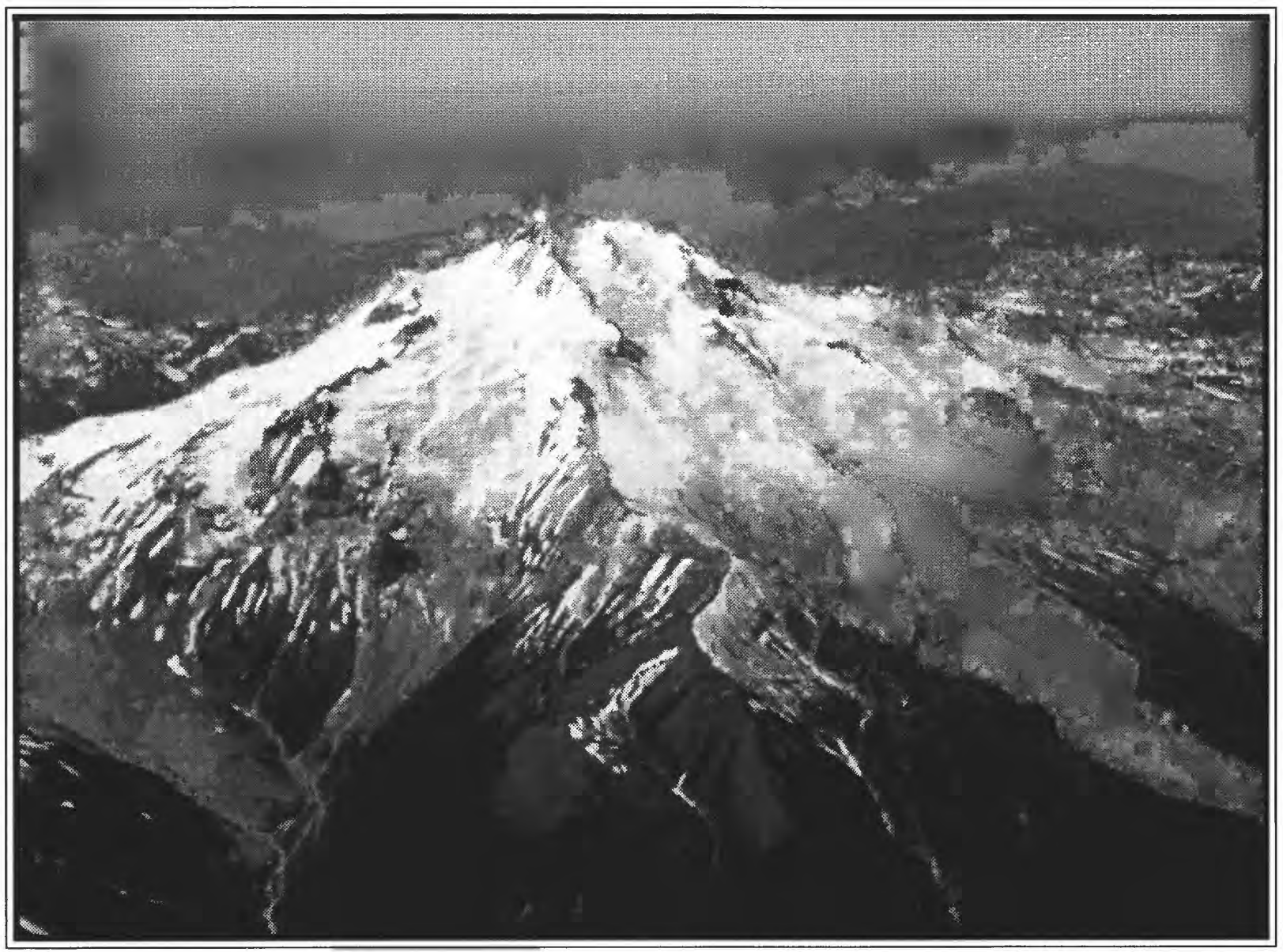

by

\section{Richard B. Waitt ${ }^{1}$, Larry G. Mastin ${ }^{1}$, and James E. Begét ${ }^{2}$}

1. U.S. Geological Survey, David A. Johnston Cascades Volcano Observatory, Vancouver, Washington

2. Department of Geology and Geophysics, University of Alaska, Fairbanks, Alaska

\section{Open-File Report 95-499}

This report is preliminary and has not been reviewed for conformity with U.S. Geological Survey editorial standards. Any use of trade, product, or firm names is for descriptive purposes only and does not imply endorsement by the U.S. Government. 


\section{CONTENTS}

Introduction 1

Volcanic phenomena 1

Tephra 1

Ballistic projectiles 2

Pyroclastic flows and pyroclastic surges 2

Lava flows and lava domes 3

Volcanic gasses 3

Debris avalanches and lateral blasts 4

Lahars

Hazards zonation 6

Tephra hazard zone 6

Lahar hazard zones 7

Pyroclastic-flow hazard zone 7

Pyroclastic-surge hazard zone 8

Lateral-blast hazard zone 8

Debris-avalanche hazard zone 8

Cited references and suggestions for further reading 9

\section{ILLUSTRATIONS}

Plate $1 \quad$ Map showing location of Glacier Peak and inferred hazard zones. Scale, 1:200,000

Figure 1. Summary of activity from Glacier Peak, based largely on Begét (1982) 2

2. Annual probability of tephra accumulation from Glacier Peak 5

3. Annual probability of tephra accumulation from all Cascade volcanoes 6

Photo credit: Glacier Peak from the east. The drainage on the left side of the photo is the headwaters of the Suiattle River. The drainage on the right side (that looks like a long, sinuous glacier) is Vista Creek (with Vista Glacier at it's head). The ridge snaking toward the camera from the summit is Gamma Ridge. Photo by Don Mullineaux, September 1964 


\title{
VOLCANIC-HAZARD ZONATION FOR GLACIER PEAK VOLCANO, WASHINGTON
}

\author{
By \\ Richard B. Waitt, Larry G. Mastin, and James E. Begét
}

\section{INTRODUCTION}

Glacier Peak, unlike other Cascade volcanoes in Washington, does not stand as a prominent backdrop to metropolitan centers. Glacier Peak's attractions, as well as its hazards, thus tend to be overlooked. Yet like most other Cascade volcanoes, Glacier Peak has erupted several times since the Ice-age glaciers retreated 15,000 years ago-most recently around the eighteenth century. Since glacial times Glacier Peak has had larger and more explosive eruptions than any Washington volcano except Mount St. Helens. If similar eruptions took place today, they could place nearby communities at serious risk. This report describes hazards that would accompany future activity at Glacier Peak and shows areas that would most likely be affected.

Volcanic hazards at Glacier Peak result from several different phenomena: tephra fall, pyroclastic flows, pyroclastic surges, ballistic ejection, debris avalanches, lahars, and floods. Lahars represent the greatest hazard, followed by tephra fall. We describe each of these phenomena, the damage it can cause, its history of occurrence at Glacier Peak (if known), and where around Glacier Peak that damage is most likely to occur.

\section{VOLCANIC PHENOMENA}

\section{Tephra}

Glacier Peak and Mount St. Helens are distinct from other Washington Cascade volcanoes in their tendency to produce large, explosive eruptions that break erupting magma into small fragments and disperse it into the atmosphere. The fragments from such eruptions, which range in size from microscopic ash to meter-sized blocks, are collectively called tephra. It forms a deposit that blankets broad areas downwind from the volcano. The deposit's thickness and particle size generally decrease away from the vent. Dust-size particles can drift many hundreds or thousands of kilometers from the source.

Near the vent, large tephra fragments are capable of causing death or injury by impact, but most injuries and fatalities from tephra fall occur when tephra accumulates thickly or is wet, and thus heavy enough to collapse building roofs. Aircraft entering ash plumes may suddenly lose power and visibility. These ash clouds can be invisible to pilots and instruments in cloudy weather. Initial temperature of erupted particles may exceed 1000 degrees Celsius $\left(1800^{\circ} \mathrm{F}\right)$. Small particles cool by the time they fall back to Earth, but large ones may retain enough heat to start fires where they land.

The hazard from tephra fall is generally smaller than from other volcanic phenomena, so the tephra hazard is commonly ignored in planning responses to volcanic crises. Yet, the 1980 eruption of Mount St. Helens showed that even thin tephra accumulations can disrupt social and economic activity over broad regions. Clouds of fine ash block sunlight, diminish or eliminate visibility, and thus stop motor-vehicle travel. Ash can cause or exacerbate pulmonary problems in people and animals. Even thin tephra accumulations may ruin crops. Tephra can contaminate surface water, plug storm-sewer and even sanitary-sewer systems, and obstruct highways and irrigation canals. Wet tephra can short out power lines. Airports and 
highways can be closed for days. Ash causes abrasion and thus sharply increases wear of machinery. Near the volcano clouds of falling tephra are commonly accompanied by lightning. Tephra plumes block sunlight, sometimes causing total darkness even at midday.

Eruptions of Glacier Peak have deposited at least nine layers of pumice tephra near the volcano in postglacial time (last 15,000 years). By far the thickest deposits were laid down east, southeast, and south of the volcano during a series of powerful eruptions about 13,100 to 12,500 years ago. The presence of pumice in the tephra indicates that each of these eruptions occurred when molten, gas-rich rock (magma) reached the summit of Glacier Peak. Layers of fine volcanic ash between the coarse pumice beds record additional lesser eruptions.

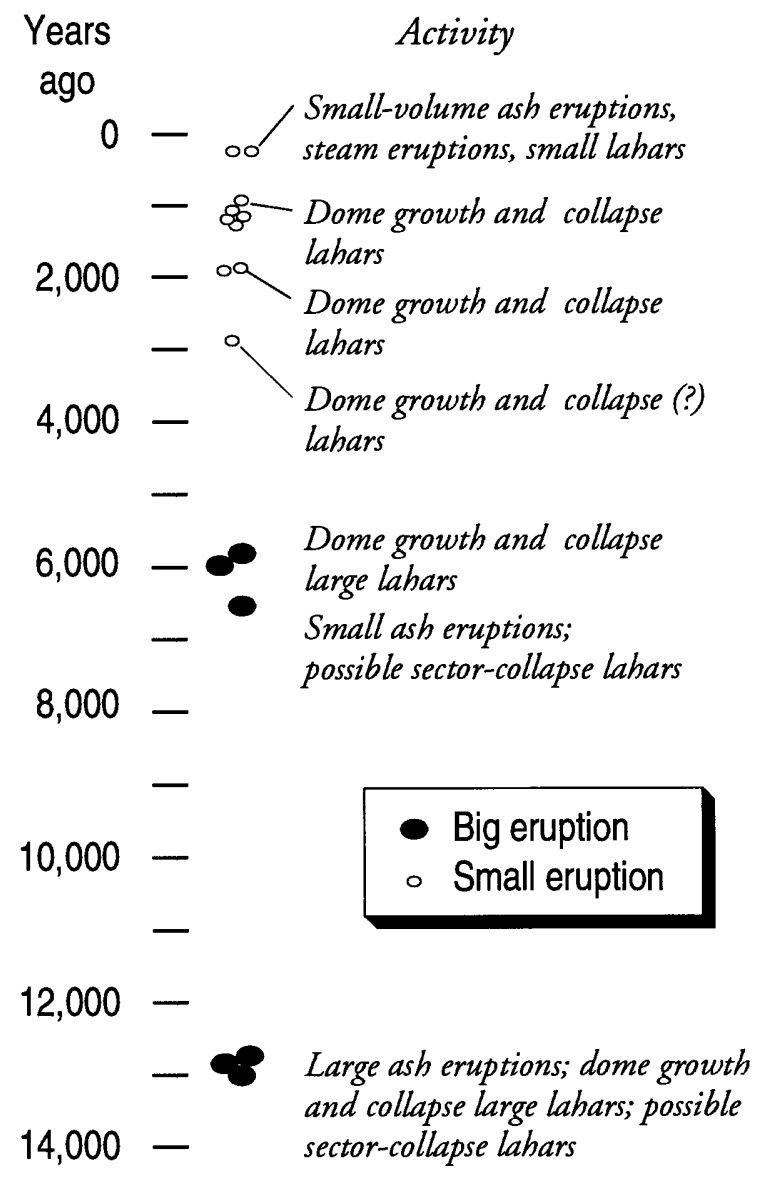

Figure 1. Summary of activity from Glacier Peak, based largely on Begét (1982). Timescale is calendar years, converted from radiocarbon years.
The volcano's magmatic eruptions have been infrequent and unequally spaced in time, making it difficult to predict when the next eruption will be. The average apparent frequency of tephra-producing eruptions is roughly 1 per 2,000 years. The volcano actually erupts more frequently, for some eruptions do not leave a conspicuous tephra layer.

\section{Ballistic Projectiles}

Large rock fragments may be ejected from the vent at very high speed and then travel downrange on ballistic trajectories-in the manner of an artillery shell, quite unlike tephra falling from a downwind-drifting tephra plume. Ballistic projectiles are rarely thrown more than $5 \mathrm{~km}$ from the vent; but unlike tephra falls they can be in directions other than downwind. The chief hazard from ballistic projectiles is direct impact. Some projectiles may still be hot when they land and could reach combustible materials.

\section{Pyroclastic Flows and Pyroclastic Surges}

During several past eruptions, Glacier Peak has delivered flows of hot gas and rock fragments to its lower flanks and beyond. Pyroclastic flows and surges are mixtures of rapidly erupted hot gases and rock fragments that flow swiftly downslope under the influence of gravity. The flow behavior of the hot fluid mixture depends on the concentration of particles. If the mixture consists mostly of rock particles, its relatively high density confines its path to topographically low areas, as a river follows a valley bottom. This phenomenon is called a pyroclastic flow. If the hot mixture is made up mostly of gas with a small proportion of rock fragments, its lower density makes its path less governed by topography. This phenomenon is called a pyroclastic surge. Pyroclastic flows and surges often occur together. Sometimes a pyroclastic flow follows the course of a valley, while an overriding pyroclastic surge separates from the pyroclastic flow and at valley bends may ride up on valley sides and even over divides. Distal parts of some pyroclastic surges carry so low a freight of particles that the deposit is too thin and fine to be 
preserved in the geologic record-yet they still can be lethal.

Pyroclastic flows and pyroclastic surges are exceedingly hazardous. They move at such speeds that escape from their paths is difficult or impossible. Speeds typically exceed $10 \mathrm{~m} / \mathrm{s}(36 \mathrm{~km} /$ h or $23 \mathrm{mi} / \mathrm{h}$ ), sometimes exceed $100 \mathrm{~m} / \mathrm{s}$ $(360 \mathrm{~km} / \mathrm{h}$ or $225 \mathrm{mi} / \mathrm{h})$. Temperatures in pyroclastic flows and pyroclastic surges are several hundred degrees Celsius or more. With its high density, high velocity, and high temperatures, a pyroclastic flow will crush, bury, and incinerate any structure or living thing in its path. Effects of a pyroclastic surge are somewhat less severe because of lower density and temperature, but a surge can affect much larger areas and still be usually lethal. People and animals caught in pyroclastic flows and surges, if not killed directly by trauma, may suffocate or later die of burns.

Deposits from pyroclastic flows and surges are part of the record of past Glacier Peak eruptions. Pyroclastic-flow deposits about 13,100 to 12,500 years old fill the floor of White Chuck valley as far as $10.5 \mathrm{~km}(6.5 \mathrm{mi})$ northwest of the summit. Pyroclastic-flow and -surge deposits about 5,500 years old lie on the east volcano flank as far as $8 \mathrm{~km}(5 \mathrm{mi})$ from the summit.

Glacier Peak, like many other Cascade volcanoes, harbors glaciers and permanent snowfields. The hot rock fragments of a turbulent, fast-moving pyroclastic flow or pyroclastic surge can swiftly melt snowpack and glacier ice, then mix with the resultant water to become a lahar (see below) or flood. Glacier Peak has produced numerous lahars and floods in the past 14,000 years, at least some of which began as pyroclastic flows or surges.

\section{Lava Flows and Lava Domes}

Much of the upper cone of Glacier Peak consists of lava flows and domes. Lava flows are streams of molten rock that erupt nonexplosively from a volcano and move downslope, where they stagnate, cool, and solidify. If lava flows accompany an explosive eruption, they usually occur after explosive activity declines. Most lava flows at Glacier Peak are composed of andesite. In contrast to the fast-moving basalt lavas commonly seen on films of Hawaiian eruptions, andesite lavas are sluggish, flowing on gentle slopes at a few tens of meters per hour. People and animals can walk from them, though any structures in the flow path are incinerated or are crushed.

During the late stages of an eruptive episode, highly viscous lava may squeeze from the vent to form a steep-sided lava dome. Dome lava flows only meters per day, and does not extend more than a few hundred meters from the vent, and thus is not especially hazardous. But energetic explosions from growing domes can occur, sometimes without warning, and are hazardous within a few kilometers of the dome. And on a steep slope huge blocks can break away from the dome, cascade down the slope, and form a hazardous fast-moving pyroclastic flow or surge.

Lava flows extend down all flanks from Glacier Peak's summit but nowhere farther than $10 \mathrm{~km}$ from the summit. Future flows would also be confined to this zone. Because the lava-flow zone lies entirely in wilderness, hazards to developed areas from lava flows are all but negligible, though secondary effects such as forest fires could reach developed areas.

\section{Volcanic Gases}

All magmas contain gases that are released both during and between eruptions. Volcanic gases consist mainly of steam but also include carbon dioxide and compounds of sulfur and chlorine. Minor amounts of carbon monoxide, fluorine and boron compounds, ammonia, and several other volcanic gases may also be present.

Volcanic gases become diluted rapidly downwind from the vent. Yet within $10 \mathrm{~km}$ of a vent, volcanic gases can endanger life and health, and sometimes property. Eyes and lungs of people and animals can be injured by acids, ammonia, and other compounds. People and animals can suffocate in denser-than-air gases like carbon dioxide, which pond and accumulate in closed depressions. Metals, glass, and other susceptible materials can severely corrode when bathed in volcanic gases.

Because the areas most likely to be affected by a Glacier Peak eruption lie far from roads, the 
hazard from volcanic gases is minor, except to hikers who may venture close.

\section{Debris Avalanches and Lateral Blasts}

At Mount St. Helens in spring 1980 a body of magma rose from depth to accumulate within the volcanic cone, causing the north flank of the volcano to bulge hundreds of meters outward. The bulging became so great that the north part of the cone suddenly detached and slid away from the rest of the volcano. As it descended, this great landslide began to break up into an avalanche of rock debris (so-called "debris avalanche"). The debris flowed $28 \mathrm{~km}$ down an adjacent valley, burying the valley floor to an average depth of 60 $\mathrm{m}$ and obliterating all objects in its path.

Fissures opening down through the moving Mount St. Helens landslide suddenly "uncorked" the deeper magma body and associated hot groundwater system, which then exploded as a huge lateral blast. This ejected mixture of gas and rock quickly developed into a gigantic pyroclastic surge whose expanding front travelled more than $20 \mathrm{~km}$ in just 4 minutes.

Both the debris avalanche and the pyroclastic surge ("blast") traveled a maximum distance of $28 \mathrm{~km}$, but the areas they affected were quite different. The avalanche followed topographic lows, so its deposit lies only along the valley just north of the volcano. The pyroclastic surge, much less directed by topography, overtopped several ridges while fanning across a 180-degree sector centered to the north, devastating a $600-\mathrm{km}^{2}$ area across valleys and ridges alike.

The danger of a debris avalanche and lateral blast resulting from shallow magma accumulation can be evaluated by monitoring large-scale premonitory bulging of the volcano, such as occurred at Mount St. Helens in the weeks before 18 May 1980. Yet a large portion of a volcanic cone may collapse and slide away without the direct involvement of magma. The interiors of many or most volcanoes are bathed in the hot, acidic waters of a groundwater system over a long period. The rock, initially solid, becomes weak as it is chemically altered to clay and other minerals. A flank of the volcanic edifice eventually may become so weak that it collapses under its own weight and slides away from the volcano flank as a debris avalanche. The depressurized hot groundwater system may then explode and generate a great pyroclastic surge. This type of collapse and resultant explosion is particularly insidious insofar as it may occur spontaneously, without warning. Collapse of part of a volcano may be triggered by a large earthquake.

The largest eruptive episodes at Glacier Peak in postglacial time may have begun with a huge debris avalanche, for the earliest lahars from each eruption contain much clay from rock altered within the volcanic cone. A collapse of part of the volcanic cone, either with or without a major eruption, could occur at Glacier Peak in the future. Two factors conducive to a noneruptive collapse and explosion-substantial volumes of hydrothermally altered rock and an active hydrothermal system-are probably present within the cone of Glacier Peak.

\section{Lahars}

Lahars, commonly called mudflows or debris flows, are slurries of sediment and water with the consistency of wet concrete that roar down stream channels and inundate valleys. They are produced when water mobilizes large volumes of loose rock, mud, or volcanic debris. Like floods, lahars inundate floodplains and submerge structures in low-lying areas. However because lahars carry mostly solid debris, they are more destructive. They destroy bridges, fill pipelines, and clog ponds and reservoirs. They can leave deposits of muddy sand and gravel that are nearly as thick as the lahars themselves. Houses, roads, pipelines, and other structures that are covered by lahars are usually lost permanently. Lahars travel farther from the volcano than any hazardous phenomenon except airfall tephra, and they affect stream valleys, where human settlement is usually greatest. For these reasons, lahars are the most serious volcanic hazard at Glacier Peak.

Lahars may be caused by both volcanic eruptions and by nonvolcanic phenomena (e.g. debris avalanches, heavy rains). Like floods, lahars range greatly in size, with the smallest recurring 
relatively frequently (every few years) and the largest recurring very infrequently (on the order of millennia). The size of lahars is controlled by both the amount of water and of loose sediment or volcanic debris available. Large debris avalanches or eruptions dump voluminous amounts of material into stream valleys and produce big lahars. Small debris avalanches or eruptions produce smaller lahars. Loose debris may also be deposited into stream channels but not mobilized to lahars until heavy rain or snowmelt provides the water.

The largest and most hazardous lahars are caused when a large portion of the volcano slides away as a giant debris avalanche. Mount St. Helens produced such a debris avalanche on 18 May 1980. This type of collapse can convert a large fraction of the volcano's edifice into a water-saturated slurry in a matter of minutes. They could reach Puget Sound in several hours. Lahars that result from mixing of erupted volcanic debris with water, snow, or ice would also be capable of reaching Puget Sound. If large or recurrent eruptions choke the headwaters of streams with volcanic debris, heavy rains could produce lahars repeatedly over many years or decades, raising the elevation of the stream channel and inundating progressively higher parts of the valley.

Since the glaciers of the Ice Age retreated from the Glacier Peak area 15,000 years ago, lahars have descended the Suiattle, White Chuck, Sauk, and Skagit River valleys during several eruptive periods. Even the North Fork Stillaguamish valley, which previously was an outflow route of the Sauk River, has been inundated by Glacier Peak lahars. Two eruptive periods (about 13,000 and 6,000 years ago), repeatedly produced large lahars, some of which reached Puget Sound. Since about 5,700 years ago, a few lahars have deposited debris as far downstream as the mouth of the White Chuck River (where it meets the Sauk River) and the lower Suiattle River valley below Buck Creek. No lahar deposits from that period have been recognized farther downstream, though flooding and other effects of the lahars surely extended farther.
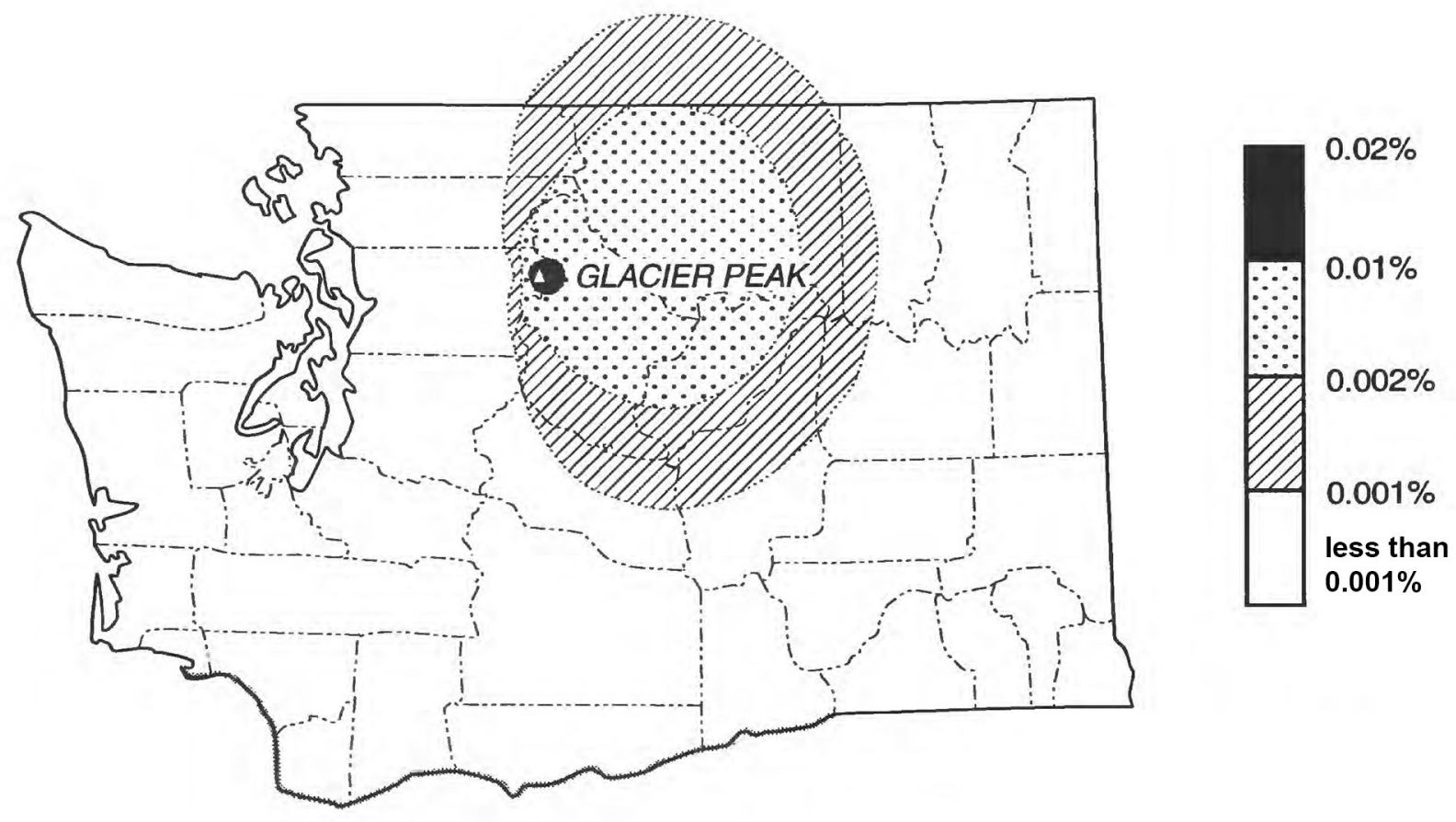

Figure 2. Annual probability of $>=10 \mathrm{~cm}$ tephra accumulation for Glacier Peak. 


\section{HAZARDS ZONATION}

\section{Tephra hazard zone}

The thickness of tephra sufficient to collapse buildings depends on construction practices and on weight of the tephra (tephra is much heavier wet than dry). Past experience in several countries shows that tephra accumulation near $10 \mathrm{~cm}$ is a threshold above which collapses tend to escalate. The tephra-hazard maps portray the estimated annual probability of tephra accumulations of $10 \mathrm{~cm}$ or more. Figure 2 considers eruptions from Glacier Peak alone, whereas Figure 3 shows the probability map when all of the Cascade volcanoes are considered together. These estimates take into account the probability that the volcano will erupt, the probability that the specified tephra thickness will occur at a particular distance, and the probability that the wind will be blowing in a specified direction. Wind in western Washington blows 90 percent of the time toward azimuths $\mathrm{N}$, NE, E, SE, or $S$, and only 10 percent of the time toward the NW, W, and SW. Figure 2 shows that tephra loading from eruptions of Glacier Peak is far more likely on the east side of the volcano within a few tens of kilometers of the summit than on the west side. No buildings lie within the

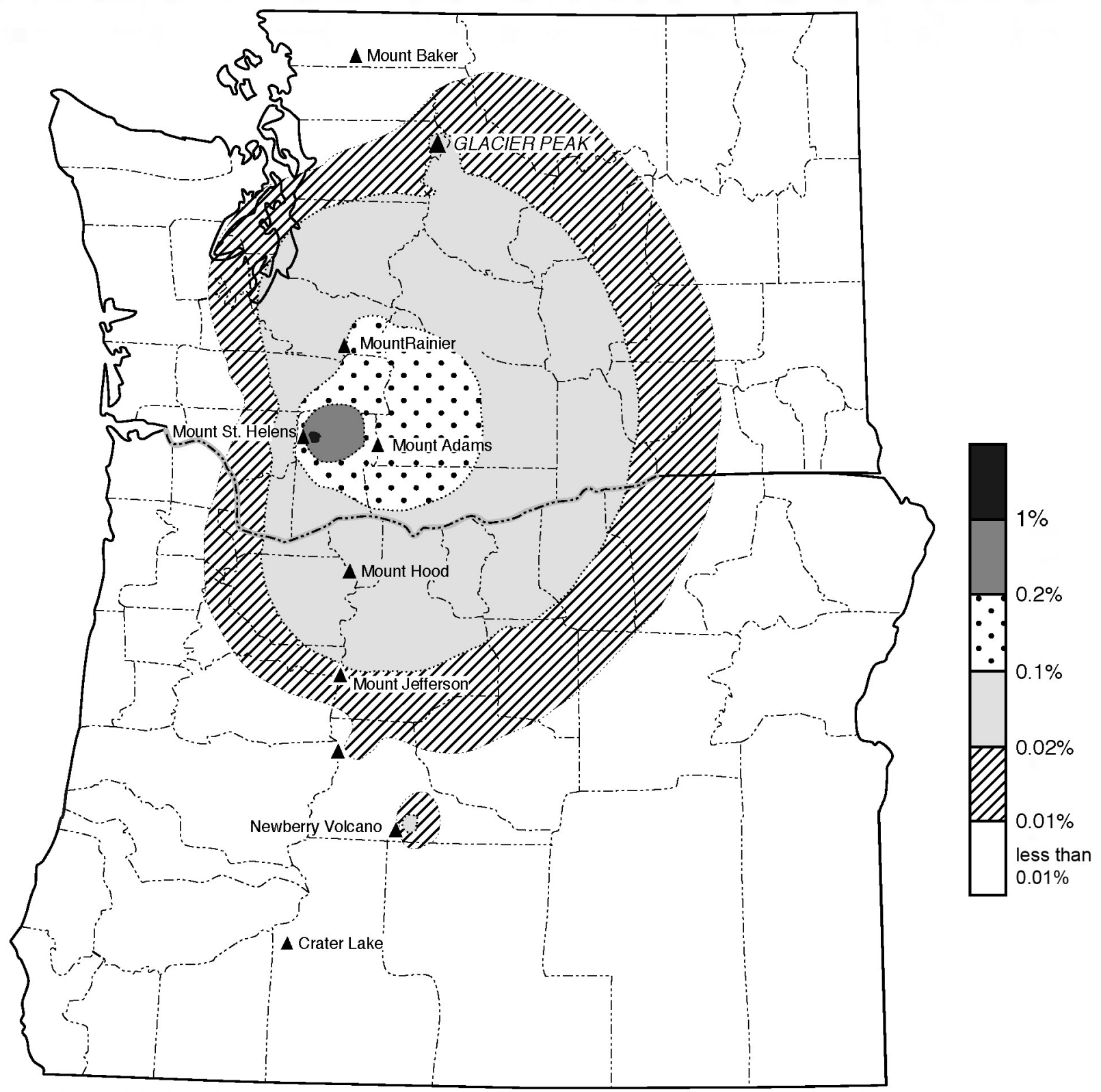

Figure 3. Annual probability of $>=10 \mathrm{~cm}$ tephra accumulation from the Cascade Range volcanoes. 
wilderness-area buffer zone. Yet any repetition of the huge eastside tephra accumulations of about 13,100 years ago would cause problems at least as far east as Chelan and other communities in Columbia valley.

\section{Lahar Hazard Zones}

The lahar hazard zone delineated on the map represents the approximate area that could be inundated by lahars originating at Glacier Peak. We hypothesize that the largest credible lahar would be caused by collapse of a significant fraction (perhaps about a third) of the volcano's edifice that lies above 6,000 feet elevation. The resulting lahar would reach the Skagit River delta in several hours and cover a significant fraction of the Skagit and Sauk flood plains with debris.

Above the Sauk-Skagit confluence, where rivers lie mostly within steep-sided valleys, the depth of inundation was estimated from relations between lahar volume, valley profiles, and inundation depths measured at Mounts Rainier and St. Helens. These empirical relations can be roughly expressed as $V /(A)^{3 / 2}=-100$, where $V$ is the volume of debris entering the river valley $\left(-0.3 \mathrm{~km}^{3}\right.$, or $-0.07 \mathrm{mi}^{3}$, for the case described above), and $\mathrm{A}$ is the inundated cross sectional area of the stream valley at a given downstream location. Near the headwaters of each stream, within the hazard zone for pyroclastic flows and debris avalanches, lahars are likely to be transitional with those phenomena and are not distinguished as a separate hazard zone. Below the Sauk-Skagit confluence, the lahar hazard zone simply covers the flood plain. Below the confluence with the Baker River, this hazard zone coincides with that drawn by Hyde and Crandell (1978, plate 1) and Gardner and others (1995) for lahars from Mount Baker.

The dashed lahar hazard zone along the Stillaguamish River valley represents the area that could potentially be inundated if the Stillaguamish River were once again to become the main drainage outflow for Glacier Peak. Most of the Stillaguamish River valley is flat or gently sloping with abrupt, steep valley walls. The edges of the lahar hazard zone were drawn along the break in slope on both sides of the valley from the Sauk-Stillaguamish drainage divide out to Puget Sound. The Stillaguamish could once again become the outflow route for streams from Glacier Peak if the Sauk River were to rise about 30 feet above its present elevation at Darrington and the outflow route to the Skagit were obstructed. This change in course would most likely be the result of large eruptions repeatedly sending debris flows down the Suiattle River, aggrading the channel at the Sauk-Suiattle confluence.

Lahars that extended at least to the lower Suiattle River or to the confluence of the White Chuck and Sauk Rivers have occurred a few times in the past 5,000 years. Their annual probability of occurrence is roughly $5 \times 10^{-4}$ to $1 \times 10^{-3}$. Probabilities of occurrence increase upstream and are on the order of $10^{-2}$ to $10^{-1}$ within a few kilometers of the headwaters of each stream. Lahars have extended from Glacier Peak to Puget Sound during at least two eruptive episodes in the past 15,000 years. This suggests an annual probability of $1 \times 10^{-4}$ to $2 \times 10^{-4}$ that a similar-sized eruptive episode would start again. The annual probability of lahars inundating the Stillaguamish River valley is thought to be less than $1 \times 10^{-4}$.

Within the lahar hazard zones, the hazard is significantly lower for structures high above the river than for those immediately on the river. The highest locations within lahar hazard zones would be inundated only by the very largest lahars, or after sequences of lahars had raised the level of the stream channel.

\section{Pyroclastic-Flow Hazard Zone}

The boundary of this hazard zone at Glacier Peak was determined using pyroclastic flows that have extended the farthest from the volcano in the past 14,000 years. The outer limit of this zone is approximated by the ratio $H / L$, where $\mathrm{H}$ is altitude difference between the eruptive vent and the farthest point reached by the flow or surge, and $\mathrm{L}$ is the horizontal (map) distance between those two points. The value $H / L=0.2$ is used to construct the hazard-zone boundary, the eruptive vent assumed to be the summit. The volcanic-hazard zone is irregular because the 
topography around Glacier Peak strongly influences the paths of valley-hugging pyroclastic flows.

In future eruptions, pyroclastic flows and ballistic projectiles will probably be contained within this zone; lava flows will certainly be. Most eruptions are to some extent directional because for instance a new summit vent may be closer to one flank than another. Thus some drainages may be completely unaffected by these phenomena while other drainages may be partly or wholly affected. Monitoring the early stages of unrest before eruption can help to predict which directions are likely to become most affected during eruption.

According to ages of tephra layers, the average eruption frequency is once in 2,000 years or less. The annual probability of pyroclastic flows, ballistic projectiles, and lava flows affecting part of the pyroclastic-flow hazard zone is thus greater than about 0.0005 .

\section{Pyroclastic-Surge Hazard Zone}

Pyroclastic surges can travel well beyond the range of pyroclastic flows. The boundary of the hazard zone for pyroclastic surge was determined with a "mobility" similar to that of a small pyroclastic surge during an eruption of Redoubt volcano, Alaska, in February 1990. The value $H / L=0.14$ is used to define the extent of the hazard zone, and the eruptive vent assumed to be the summit. Gigantic surges with $\mathrm{H} / \mathrm{L}$ ratios less than 0.14 have occurred at certain volcanoes but under circumstances that do not seem to exist at Glacier Peak. The volcanic-hazard zone is irregular because of the irregular topography around Glacier Peak, which influences the paths of pyroclastic surges.

In future eruptions, pyroclastic surges will probably be contained within this zone. Because most eruptions are to some extent directional, some drainages may be completely unaffected while other drainages may be partly or wholly swept by pyroclastic surge.

\section{Lateral-Blast Hazard Zone}

The zone potentially at risk from a laterally directed volcanic blast such as occurred at Mount
St. Helens in 1980 is shown on the accompanying map. The boundary of the hazard zone was determined for a flowage with a mobility equal to that of the segment of the 1980 Mount St. Helens blast-in essence a gigantic pyroclastic surge-that travelled north-northeast over rough topography. For this case the value $H / L=0.10$ is used and the eruptive vent is again assumed to be the summit. Because Glacier Peak is of similar height to Mount St. Helens while nearby topographic relief is greater, the potential blast hazard zone is slightly smaller than the actual 1980 Mount St. Helens blast zone. The Glacier Peak blast-hazard zone is irregular because of topographic barriers would block a blast flowing to the northeast or southwest. Topography would strongly channel a blast flow toward the northwest or southeast, so that it would reach far out only along valleys-farthest on the northwest.

A lateral volcanic blast from Glacier Peak would not affect the entire zone potentially at risk. Experience at Mount St. Helens and other volcanoes shows that a blast would most likely affect an arc of 90 to 180 degrees, not the entire 360 degrees. During a volcanic crisis, the likelihood of a laterally directed blast could be assessed by monitoring deformation of the flanks of the volcano. Formation of a bulge, as occurred in 1980 at Mount St. Helens in the weeks before the climactic eruption, would signal the strong likelihood of a lateral blast in that direction. A refined blast-hazards map could then be prepared indicating areas at greatest risk.

\section{Debris-Avalanche Hazard Zone}

A huge debris avalanche may occur even without an eruption, possibly without warning. The best-known historic debris avalanche is that which occurred at Mount St. Helens on 18 May 1980. Its $\mathrm{H} / \mathrm{L}$ ratio in areas close to the volcano was about 0.19 (measured from former summit), but once it settled into a valley, it flowed far downvalley such that the H/L ratio at its toe is 0.11 . Thus in proximal areas the hazard zone at Glacier Peak is similar to that depicted for pyroclastic flows, while in potentially affected valleys-White Chuck and Suiattle-its limit is similar to that depicted for lateral blast. 


\section{Suggestions for Further Reading}

\section{General Literature}

Blong, R.J., 1984, Volcanic Hazards: Orlando, Academic Press, $424 \mathrm{p}$.

Crandell D.R., Booth, B., Kusumadinata, K., Shimozuru, Walker, G.P.L., and Westercamp, D., 1984, Source-book for volcanic-hazard zonation: Paris, UNESCO, $97 \mathrm{pp}$.

Hoblitt, R.P., Miller, C.D., and Scott, W.E., 1987, Volcanic hazards with regard to siting nuclear-power plants in the Pacific Northwest: U.S. Geological Survey Open-File Report 87-297, 196 p.

Schuster, R.L., 1981, Effects of the eruptions on civil works and operations in the Pacific Northwest, in Lipman, P.W., and Mullineaux, D.R., eds., The 1980 eruptions of Mount St. Helens, Washington: U.S. Geological Survey Professional Paper 1250, p. 701-718.

Sheridan, M.F., 1979, Emplacement of pyroclastic flows: a review: in Chapin, C.E., and Elston, W.E., eds., Ash-Flow Tuffs, Geological Society of America Special Paper 180, p. 125-136.

Tilling, R.I., ed., 1989, Volcanic Hazards: Washington, D.C., Short Course in Geology, Vol. 1, American Geophysical Union, 123 p.

\section{Glacier Peak Volcano}

Begét, J.E., 1982, Postglacial volcanic deposits at Glacier Peak, Washington, and potential hazards from future eruptions: U.S. Geological Survey Open-File Report $82-830,77 \mathrm{p}$.

Begét, J.E., 1982, Recent volcanic activity at Glacier Peak: Science, v. 215, p. 1389-1390.

Begét, J.E., 1983, Glacier Peak, Washingtonpotentially hazardous Cascade volcano: Environmen Geology, v. 5, p. 83-92.
Crowder, D.F., Tabor, R.W., and Ford, A.B., 1966, Geologic map of the Glacier Peak quadrangle, Snohomish and Chelan Counties, Washington: U.S. Geological Survey Geologic Quadrangle Map GQ-473.

Porter, S.C., 1978, Glacier Peak tephra in the North Cascade Range, Washington-stratigraphy, distribution, and relationship to late-glacial events: Quaternary Research, v. 10, p. 30-41.

Tabor, R.W., and Crowder, D.F., 1969, On batholiths and volcanoes-intrusion and eruption of late Cenozoic magma in the Glacier Peak area, North Cascades, Washington: U.S. Geological Survey Professional Paper 604, 67 p.

\section{Other Cascade Volcanoes}

Frank, D., Meier, M.F., and Swanson, D.A., 1977, Assessment of increased thermal activity at Mount Baker, Washington, March 1995-March 1976: U.S. Geological Survey Professional Paper 1022-A, 49 p.

Gardner, C. A., Scott, K.M., Miller, C.D., Myers, Bobbie, Hildreth, Wes, and Pringle, P.T., 1995, Potential volcanic hazards from future activity of Mount Baker, Washington: U.S. Geological Survey Open-File Report 95-498, 16 p.

Hyde, J.H., and Crandell, D.R., 1978, Postglacial volcanic deposits at Mount Baker, Washington, and potential hazards from future eruptions: U.S. Geological Survey Professional Paper 1022-C, 17 p.

Saarinern, T.F. and Sell, J.L., 1985, Warning and response to the Mount St. Helen's Eruption: Albany, State University of New York Press, $240 \mathrm{p}$.

Scott, K.M., and Vallance, J.W., 1995, Debris flow, debris avalanche, and flood hazards at and downstream from Mount Rainier, Washington: U.S. Geological survey Hydrologic Investigations Atlas HA-729: 1:100,,000 scale
For additional information, write to:

\author{
U.S. Geological Survey \\ Cascades Volcano Observatory \\ 5400 MacArthur Boulevard \\ Vancouver, WA 98661
}

Copies of this report can be purchased from:

\author{
U.S. Geological Survey \\ Earth Science Information Center \\ Open-File Reports Section \\ Box 25286, MS 517 \\ Denver Federal Center \\ Denver, CO 80225
}

